\title{
Penilaian Sumber Pencemar Non Logam di Waduk Asin Pusong Kota Lhokseumawe Berdasarkan Analisis Multivariat
}

\author{
Riri Ezraneti, Syahrial*, Erniati \\ Program Studi IImu Kelautan Fakultas Pertanian, Universitas Malikussaleh \\ Kampus Cot Teungku Nie Reuleut Muara Batu Aceh Utara Provinsi Aceh 24355 Indonesia \\ Email: syahrial.marine@unimal.ac.id
}

\begin{abstract}
Assessment of Non-Metallic Pollutant Sources in Salt Water Reservoir Pusong in Lhokseumawe City Based on Multivariate Analysis
\end{abstract}

Human anthropogenic activities have resulted in an important transformation in the aquatic environment for decades, so the study of the assessment of non-metallic pollutant sources in the salty reservoir Pusong in Lhokseumawe City was conducted in October 2020 which was reviewed based on multivariate analysis. The study aims to find out the source of non-metallic pollutants in the salt reservoir waters of Pusong Kota Lhokseumawe with the collection of primary data conducted by observation at five observation stations, where water samples are taken using van dorn water sampler at a depth of $\pm 0-1 \mathrm{~m}$ with three repetitions per station. The results showed that non-metallic contaminants of total ammonia nitrogen, nitrate, and phosphate had exceeded the established quality standards ( $>5.00 \mathrm{mg} / \mathrm{L},>0.30 \mathrm{mg} / \mathrm{L},>0.008 \mathrm{mg} / \mathrm{L}$ and $>0.015 \mathrm{mg} / \mathrm{L}$ ), then based on PCA analysis, eigenvalues of each variable indicate the formation of two new components namely Component 1 consisting of non-metallic nitrate contaminants and total nitrogen ammonia (3.05), while Component 2 consists of non-metallic contaminants total coliform and $\mathrm{BOD}_{5}$ (1.93) with a data diversity of $82.99 \%$. Besides, non-metallic contaminants of total nitrogen ammonia, as well as phosphates, have a significant relationship to temperature parameters, while non-metal nitrate contaminants have significant links to $\mathrm{pH}$ parameters, turbidity, and salinity. Furthermore, the complexity of the study area between observation stations based on CA analysis was divided into two groups, the first group consisted of Stations 2, 4, and 5 with non-metallic contaminants source nitrate, $\mathrm{BOD}_{5}$ as well as total coliform, while the second group consisted of Stations 1 and 3 with non-metallic contaminants of total ammonia nitrogen, phosphate, and surfactants.

Keywords : non-metal, water quality, multivariate analysis, Salt Water Reservoir Pusong

\begin{abstract}
Abstrak
Kegiatan antropogenik manusia telah menghasilkan transformasi penting dalam lingkungan akuatik selama beberapa dekade, sehingga kajian penilaian sumber pencemar non logam di waduk asin Pusong Kota Lhokseumawe dilakukan pada bulan Oktober 2020 yang ditinjau berdasarkan analisis multivariat. Kajian bertujuan untuk mengetahui sumber pencemar non logam di perairan waduk asin Pusong Kota Lhokseumawe dengan pengumpulan data primernya dilakukan secara observasi di lima stasiun pengamatan, dimana sampel air diambil menggunakan van dorn water sampler pada kedalaman $\pm 0-1 \mathrm{~m}$ dengan tiga kali pengulangan setiap stasiunnya. Hasil kajian memperlihatkan bahwa sumber pencemar non logam total amonia nitrogen, nitrat maupun fosfat sudah melebihi baku mutu yang telah ditetapkan $(>5.00 \mathrm{mg} / \mathrm{L},>0.30$ $\mathrm{mg} / \mathrm{L},>0.008 \mathrm{mg} / \mathrm{L}$ dan $>0.015 \mathrm{mg} / \mathrm{L}$ ), kemudian berdasarkan analisis PCA, nilai eigen dari masingmasing variabel mengindikasikan adanya pembentukan dua komponen baru yaitu Component 1 terdiri dari sumber pencemar non logam nitrat dan total amonia nitrogen (3.05), sedangkan Component 2 terdiri dari sumber pencemar non logam total coliform dan BOD5 (1.93) dengan keragaman datanya sebesar $82.99 \%$. Selain itu, sumber pencemar non logam total amonia nitrogen maupun fosfat memiliki hubungan yang signifikan terhadap parameter suhu, sedangkan
\end{abstract}


sumber pencemar non logam nitrat memiliki hubungan yang signifikan terhadap parameter $\mathrm{pH}$, kekeruhan dan salinitas. Selanjutnya, kompleksitas wilayah studi antar stasiun pengamatan berdasarkan analisis CA terbagi atas dua kelompok, kelompok pertama terdiri dari Stasiun 2, 4 dan 5 dengan sumber pencemar non logam nitrat, $\mathrm{BOD}_{5}$ serta total coliform, sedangkan kelompok kedua terdiri dari Stasiun 1 dan 3 dengan sumber pencemar non logam total amonia nitrogen, fosfat serta surfaktan.

Kata kunci : non logam, kualitas air, analisis multivariat, waduk asin Pusong

\section{PENDAHULUAN}

yang dir merupakan sumberdaya terpenting kehidupan makhluk hidup (Paul, 2017) dan membentuk konstituen utama dari ekosistem (Effendi, 2016). Pertumbuhan populasi hingga semakin pesatnya perkembangan ekonomi saat ini telah menyebabkan meningkatnya masukkan air limbah (polutan) ke sistem perairan (Hamzah dan Setiawan, 2010; Dsikowitzky et al., 2011; Tyagi et al., 2013), dimana polutan yang melebihi muatan alami telah menjadi permasalahan yang serius (Wolf dan Rashid, 2008) seperti halnya Sungai Msimbazi Tanzania yang menerima limbah industri maupun antropogenik dengan ratarata 256 - $606 \mathrm{~m}^{3} / \mathrm{jam}$ (Ak'habuhaya dan Lodenius, 1988). Menurut Machiwa (1992) keberadaan kawasan permukiman penduduk (rumah tangga) dapat mengakibatkan pembuangan limbah domestik yang belum/tidak terdegradasi dan terdekomposisi secara sempurna, sehingga menyebabkan terjadinya pencemaran (Supriyantini et al., 2017).

Di Kota Lhokseumawe Provinsi Aceh, terdapat salah satu waduk yang perairannya bersalinitas tinggi (asin) dan diberi nama Waduk Pusong, dimana keberadaan waduk tersebut berjarak $\pm 2 \mathrm{~km}$ dari Kota Lhokseumawe. Waduk ini dibangun pada tahun 2010 dengan daya tampungnya sekitar $850.000 \mathrm{~m}^{3}$ (Khatab dan Indrawan, 2013) dan berbatasan dengan Desa Pusong Lama di bagian Timur maupun Desa Mon Geudong di bagian Baratnya. Rencana pembangunannya, waduk asin Pusong Kota Lhokseumawe digunakan sebagai kawasan pencegah banjir. Namun seiring berjalannya waktu, waduk asin Pusong Kota Lhokseumawe juga dimanfaatkan sebagai tempat wisata dan area budidaya keramba jaring tancap oleh masyarakat setempat, kemudian di sekitar waduk tersebut juga terdapat permukiman penduduk serta pasar tradisional, sehingga secara tidak langsung Waduk asin Pusong Kota Lhokseumawe menerima buangan limbah hasil dari aktivitas-aktivitas tersebut.

Terlepas dari hal di atas, analisis multivariat merupakan metode analisis komprehensif yang meliputi analisis pengelompokan (Cluster Analysis/ CA), analisis diskriminan, analisis regresi, analisis komponen utama (Principal Component Analysis/PCA), analisis faktor, analisis korespondensi, analisis korelasi kanonik serta analisis jalur (Path Analysis) yang dapat digunakan dalam berbagai objek, sehingga banyak digunakan dalam menginterpretasi data lingkungan (Einax dan Soldt, 1999; Mico et al., 2006; Araujo et al., 2013, Khwedim et al., 2015, Singh dan Ramanathan, 2015; Syahrial et al., 2017; Syahrial et al., 2018a,b; Syahrial dan Novita, 2018; Syahrial, 2019; Syahrial et al., 2019a,b,c). Hal ini disebabkan karena analisis multivariat sangat mudah membedakan antara masukan (input) alami dengan masukan hasil dari aktivitas manusia (antropogenik) (Garcıa et al., 1996; Facchinelli et al., 2001; Lucho-Constantino et al., 2005). Selain itu, analisis multivariat juga dapat menganalisis data dalam jumlah yang sangat besar (Lins et al., 2018), memberi evaluasi yang cepat dari pola spasial temporal ruang ataupun asosiasi antar variabel lingkungan, serta sangat efisien dalam menyaring gangguan (noise) dari kumpulan-kumpulan data yang besar (Bierman et al., 2011; Yan et al., 2012).

Di samping itu, penilaian spasial terhadap sumber pencemaran juga telah sering dijadikan sebagai informasi dalam mengidentifikasi dan meramal tren kualitas air di suatu perairan (Prasad dan Sangita, 2008; 
Reza dan Singh, 2010), sehingga kajian-kajian terhadap pencemaran perairan telah banyak dilakukan (Sandra et al., 2016; Ejiadi et al., 2017; Saily et al., 2018; Sumiarsih et al., 2018; Handoko et al., 2018; Ismi et al., 2019; Johar, 2019). Namun, kajian terhadap pencemaran di perairan waduk asin Pusong Kota Lhokseumawe, khususnya limbah atau bahan pencemar non logam masih sangat jarang dilakukan. Oleh karena itu, kajian tersebut sangat perlu dilakukan dengan tujuan untuk mengetahui sumber pencemar non logam di perairan waduk asin Pusong Kota Lhokseumawe.

\section{MATERI DAN METODE}

Kajian dilaksanakan pada bulan Oktober 2020 di waduk asin Pusong Kota Lhokseumawe dengan pengumpulan data primernya dilakukan secara observasi (survei lapangan) di lima stasiun pengamatan yang dianggap mewakili perairan tersebut (Tabel 1 dan Gambar 1). Stasiun 1 berada di sekitar jalan masuk stadion yang berdekatan dengan pintu masuk (inlet) limbah rumah tangga dari Desa Mon Geudong, sedangkan Stasiun 2 berada di sekitar pintu masuk limbah aktivitas pasar Lhokseumawe, dimana di sekitar stasiun ini juga terdapat keramba jaring tancap di perairannya. Untuk Stasiun 3 berada di persimpangan jalur masuk menuju stadion pemerintahan Kota Lhokseumawe dan di sekitar kawasan ini sering dijadikan sebagai tempat penumpukan sampah bagi warga sekitarnya dan juga terdapat beberapa keramba jaring tancap di perairannya. Selanjutnya, untuk Stasiun 4 berada di sekitar area rekreasi dan berdekatan dengan pintu masuk maupun keluarnya air laut ke dalam waduk (sebagai pintu pengontrolan waduk) serta di sekitarnya juga terdapat banyak keramba jaring tancap di perairannya, sedangkan Stasiun 5 berada di pertengahan waduk.

Sampel air diambil menggunakan van dorn water sampler pada kedalaman $\pm 0-1$ $m$, dimana pengambilan sampel airnya dilakukan sebanyak tiga kali pengulangan setiap stasiunnya, kemudian dimasukan ke dalam botol plastik $500 \mathrm{ml}$ dan dikumpulkan ke dalam ice box serta diawetkan dengan batu es. Untuk sampel air $\mathrm{BOD}_{5}$ dimasukan ke dalam botol kaca gelap $300 \mathrm{ml}$, kemudian disimpan pada suhu $20^{\circ} \mathrm{C}$, sedangkan untuk sampel total coliform dimasukkan ke dalam botol kaca steril dengan membakar bagian mulut botol terlebih dahulu sebelum dimasukkan sampel airnya (untuk menghindari masuknya mikroorganisme selain dari air) dan setelah dimasukkan sampel air, mulut botol maupun tutup botol tersebut dibakar kembali. Sampel air untuk $B O D_{5}$, total amonia nitrogen, nitrat, fosfat, surfaktan dan total coliform yang sudah diperoleh, selanjutnya dianalisis di Laboratorium Hatchery dan Teknologi Budidaya Program Studi Budidaya Perairan Fakultas Pertanian Universitas Malikussaleh. Sementara untuk parameter suhu, kekeruhan, $\mathrm{pH}$, salinitas dan oksigen terlarut, pengukurannya dilakukan secara in situ menggunakan alat thermometer, turbidimeter, $\mathrm{pH}$ meter, hand refraktometer dan DO meter.

Penentuan kualitas perairan waduk asin Pusong Kota Lhokseumawe, data primer yang sudah diperoleh selanjutnya dibandingkan dengan baku mutu lingkungan menurut Keputusan Menteri Negara Lingkungan Hidup Nomor 51 Tahun 2004 tentang Baku Mutu Air Laut untuk Biota.

Tabel 1. Koordinat kajian analisis kualitas air dan indeks pencemaran di waduk asin Pusong Kota Lhokseumawe

\begin{tabular}{lccc}
\hline \multirow{2}{*}{ Lokasi } & \multirow{2}{c}{ Stasiun } & \multicolumn{2}{c}{ Koordinat } \\
\cline { 3 - 4 } & & $\mathrm{N}$ & $\mathrm{E}$ \\
\hline Pintu masuk dari Mon Geudong & 1 & $05^{\circ} 10^{\prime} 21.82^{\prime \prime}$ & $97^{\circ} 08^{\prime} 27.66^{\prime \prime}$ \\
Pintu masuk aktivitas pasar Lhokseumawe & 2 & $05^{\circ} 10^{\prime} 13.81^{\prime \prime}$ & $97^{\circ} 08^{\prime} 45.59^{\prime \prime}$ \\
Jalur masuk stadion Lhokseumawe & 3 & $05^{\circ} 10^{\prime} 09.37^{\prime \prime}$ & $97^{\circ} 08^{\prime} 29.42^{\prime \prime}$ \\
Pintu masuk dan keluarnya air laut & 4 & $05^{\circ} 09^{\prime} 58.24^{\prime \prime}$ & $97^{\circ} 08^{\prime} 37.82^{\prime \prime}$ \\
Pertengahan waduk & 5 & $05^{\circ} 10^{\prime} 03.54^{\prime \prime}$ & $97^{\circ} 08^{\prime} 36.98^{\prime \prime}$ \\
\hline
\end{tabular}


Sementara untuk mengetahui sumber pencemar non logam yang mencemari perairan waduk asin Pusong Kota Lhokseumawe, parameter lingkungan yang diperoleh dianalisis menggunakanstatistik multivariat Principal Component Analysis (PCA) dan Cluster Analysis (CA), dimana analisis PCA dan CA dilakukan dengan software SPSS versi 24 (Radiarta et al., 2013) (Hammer et al., 2001; Satheeshkumar dan Khan, 2012; Kumar et al,. 2018). PCA diinterpretasikan sesuai dengan hasil rotasi varimaxnya. Hal ini karena rotasi ortogonal pada rotasi varimax PCA dapat meminimal jumlah variabel di setiap komponennya serta memfasilitasi interpretasi hasil dari rotasi varimaxnya (Mico et al., 2006), sehingga hasil yang diperoleh lebih dapat ditafsirkan. Sementara, untuk mengidentifikasi hubungan antara sumber pencemar non logam dengan karakteristik kualitas perairan waduk asin Pusong Kota Lhokseumawe (suhu, kekeruhan, salinitas, $\mathrm{pH}$ dan DO) dianalisis menggunakan korelasi matriks, sedangkan untuk mengidentifikasi kelompok-kelompok sumber pencemar non logam yang berbeda di perairan waduk asin Pusong Kota Lhokseumawe, dianalisis menggunakan statistik multivariat CA dengan metode Ward (Ward's method) dan hasilnya ditampilkan dalam bentuk dendogram (diagram pohon).

\section{HASIL DAN PEMBAHASAN}

Parameter kualitas perairan dan sumber pencemar non logam waduk asin Pusong Kota Lhokseumawe yang diukur memliki konsentrasi yang bervariasi setiap stasiunnya, dimana untuk suhu berada pada Stasiun $4\left(32.50^{\circ} \mathrm{C}\right)$, kekeruhan Stasiun 1 (06.83 NTU), $\mathrm{pH}$ Stasiun 1 dan 3 (07.20), salinitas Stasiun 4 dan 5 (30.50\%o), DO Stasiun 1 (06.76 $\mathrm{mg} / \mathrm{L}), \mathrm{BOD}_{5}$ Stasiun $2(08.50 \mathrm{mg} / \mathrm{L})$, total amonia nitrogen Stasiun 3 (00.67 mg/L), nitrat Stasiun 4 (04.70 mg/L), fosfat Stasiun 3 (00.74 $\mathrm{mg} / \mathrm{L}$ ), surfaktan Stasiun 1 (00.47 mg/L MBAS) dan total coliform Stasiun $3(530 / 100 \mathrm{ml})$ (Tabel 2). Secara keseluruhan, bila dibandingkan dengan Keputusan Menteri Negara Lingkungan Hidup Nomor 51 Tahun 2004 tentang Baku Mutu Air Laut untuk biota, maka konsentrasi oksigen terlarut, total amonia nitrogen, nitrat maupun fosfat di perairan waduk asin Pusong Kota Lhokseumawe sudah melebihi baku mutu yang telah ditetapkan (>5.00 mg/L, > 0.30 $\mathrm{mg} / \mathrm{L},>0.008 \mathrm{mg} / \mathrm{L}$ dan $>0.015 \mathrm{mg} / \mathrm{L})$. Tingginya konsentrasi oksigen terlarut di perairan tersebut diduga karena pencampuran massa air yang lebih baik, kemudian dapat juga disebabkan oleh tingginya proses fotosintesis yang terjadi serta dapat juga disebabkan oleh rendahnya

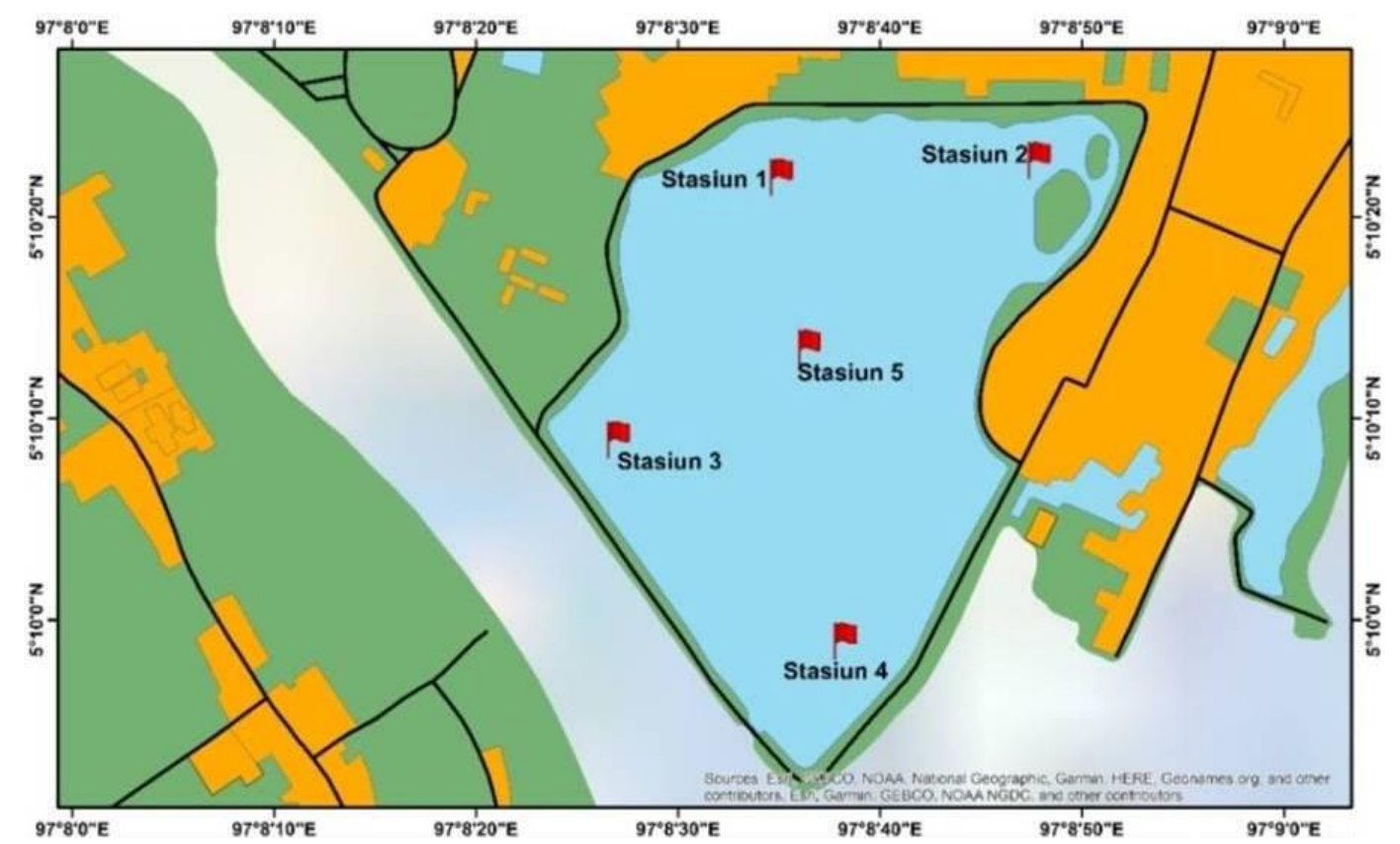

Gambar 1. Peta lokasi kajian 
konsentrasi suhu perairan. Sementara tingginya konsentrasi total amonia nitrogen di perairan waduk asin Pusong Kota Lhokseumawe diduga karena intensifnya pemberian pakan oleh nelayan keramba jaring tancap yang berada di perairan tersebut. Hal ini sangat berpotensi terhadap peningkatan pertumbuhan maupun kepadatan fitoplankton, kemudian tingginya konsentrasi nitrat di perairan waduk asin Pusong Kota Lhokseumawe diduga karena tingginya kandungan oksigen terlarut di perairannya yang menyebabkan proses nitrifikasi menjadi lebih cepat.

Selain itu, tingginya konsentrasi nitrat di perairan waduk asin Pusong Kota Lhokseumawe juga dapat disebabkan oleh tingginya bahan organik yang terkandung di perairannya, dimana pertumbuhan bakteri nitrifikasi menjadi lebih lambat disebabkan karena mengurai bahan organik tersebut, kemudian tingginya konsentrasi nitrat di perairan waduk asin Pusong Kota Lhokseumawe juga dapat disebabkan oleh pengaruh massa air tawar yang masuk ke perairan waduk, dimana masukan tersebut banyak membawa senyawa-senyawa nitrogen dari daratan. Selanjutnya, tingginya konsentrasi fosfat di perairan waduk asin Pusong Kota Lhokseumawe diduga disebabkan oleh pembuangan limbah domestik dari permukiman sekitar, terutama pembuangan cucian pakaian yang banyak mengandung deterjen, kemudian dapat juga disebabkan oleh adanya pelepasan nitrogen (N) dan fosfor (P) dari pakan keramba jaring tancap, dimana baik itu nitrogen (N) maupun fosfor (P), keduanya merupakan unsur penting yang terdapat dalam suatu pakan formulasi bagi pertumbuhan ikan (Sukadi, 2010) dan asupan $\mathrm{N}$ maupun $\mathrm{P}$ pada pakan ikan tersebut hanya sekitar 20 atau $30 \%$ yang diasimilasi oleh ikan (Ramseyer dan Garling, 1997), sedangkan sisanya terbuang ke lingkungan yang dapat menyebabkan pencemaran (Sukadi, 2010).

Berdasarkan analisis PCA yang dilakukan, nilai eigen dari masing-masing variabel mengindikasikan adanya pembentukan dua komponen baru (nilai eigen lebih besar dari satu, baik itu sebelum maupun sesudah dilakukannya rotasi matriks) yaitu Component 1 sebesar 3.05 dan Component 2 sebesar 1.93, dimana keragaman data untuk kedua komponen tersebut sekitar $82.99 \%$ (Tabel 3) dengan Component 1 terdiri dari sumber pencemar non logam nitrat dan total amonia nitrogen, sedangkan Component 2 terdiri dari sumber pencemar non logam total coliform dan $\mathrm{BOD}_{5}$. Selain itu, Tabel 3 juga memperlihatkan bahwa Component 1 (sumber pencemar non logam nitrat dan total amonia nitrogen) memiliki varian sebesar $50.84 \%$, sedangkan Component 2 (sumber pencemar non logam total coliform dan BOD5) sebesar $32.15 \%$, sehingga Component 1 merupakan parameter yang paling berpotensi sebagai sumber pencemar non logam di perairan

Tabel 2. Parameter kualitas perairan waduk asin Pusong Kota Lhokseumawe

\begin{tabular}{|c|c|c|c|c|c|c|}
\hline \multirow{2}{*}{$\begin{array}{l}\text { Parameter } \\
\text { Kualitas Air }\end{array}$} & \multicolumn{6}{|c|}{ Stasiun Pengamatan } \\
\hline & 1 & 2 & 3 & 4 & 5 & aBaku Mutu \\
\hline Suhu $\left({ }^{\circ} \mathrm{C}\right)$ & $30.50 \pm 00.71$ & $31.00 \pm 01.41$ & $30.50 \pm 00.71$ & $32.50 \pm 00.71$ & $31.00 \pm 00.00$ & $28.00-32.00$ \\
\hline Kekeruhan (NTU) & $06.83 \pm 00.98$ & $04.75 \pm 00.17$ & $06.04 \pm 01.32$ & $03.39 \pm 00.71$ & $03.18 \pm 01.13$ & $<05.00$ \\
\hline $\mathrm{pH}$ & $07.20 \pm 00.00$ & $07.15 \pm 00.07$ & $07.20 \pm 00.14$ & $07.05 \pm 00.21$ & $07.00 \pm 00.28$ & $07.00-08.50$ \\
\hline Salinitas (\%o) & $27.50 \pm 00.71$ & $30.00 \pm 01.41$ & $28.50 \pm 00.71$ & 30.5000 .71 & $30.50 \pm 00.71$ & $00.33-00.34$ \\
\hline $\mathrm{DO}$ (mg/L) & $06.76 \pm 00.24$ & $06.29 \pm 00.39$ & $06.69 \pm 00.16$ & $06.55 \pm 00.09$ & $06.57 \pm 00.16$ & $>00.50$ \\
\hline $\mathrm{BOD}_{5}$ (mg/L) & $04.80 \pm 00.99$ & $08.50 \pm 04.38$ & $07.00 \pm 02.97$ & $05.80 \pm 01.41$ & $07.60 \pm 03.54$ & 00.20 \\
\hline $\begin{array}{c}\text { Total amonia } \\
\text { nitrogen (mg/L) }\end{array}$ & $00.66 \pm 00.00$ & $00.62 \pm 00.53$ & $00.67 \pm 00.24$ & $00.24 \pm 00.07$ & $00.40 \pm 00.14$ & 00.30 \\
\hline Nitrat (mg/L) & $03.35 \pm 01.48$ & $04.50 \pm 00.14$ & $04.25 \pm 00.21$ & $04.70 \pm 00.28$ & $04.75 \pm 00.07$ & 00.008 \\
\hline Fosfat (mg/L) & $00.63 \pm 00.18$ & $00.48 \pm 00.04$ & $00.74 \pm 00.44$ & $00.24 \pm 00.04$ & $00.31 \pm 00.00$ & 00.015 \\
\hline $\begin{array}{l}\text { Surfaktan } \\
\text { (mg/L MBAS) }\end{array}$ & $00.47 \pm 00.03$ & $00.46 \pm 00.03$ & $00.37 \pm 00.02$ & $00.38 \pm 00.03$ & $00.34 \pm 00.01$ & 01.00 \\
\hline $\begin{array}{l}\text { Total coliform } \\
\text { (MPN/100ml) }\end{array}$ & $335.00 \pm 91.92$ & $395.00 \pm 106.07$ & $530.00 \pm 141.42$ & $385.00 \pm 106.07$ & $405.00 \pm 247.49$ & 1000.00 \\
\hline
\end{tabular}


$a=$ MNLH (2004)

waduk asin Pusong Kota Lhokseumawe. Hal ini didukung dari hasil pengukuran konsentrasi yang sudah melebihi ambang batas. Aktivitas-aktivitas antropogenik yang diduga menjadi dugaan sumber pencemaran nitrat dan total amonia nitrogen di perairan waduk asin Pusong Kota Lhokseumawe adalah budidaya keramba jaring tancap maupun limbah perkotaan yang ada di sekitarnya. Hal ini didukung oleh pernyataan Environtment Canada (2003) maupun Sudaryanto dan Suherman (2008), dimana sumber nitrat di suatu perairan dapat berasal dari buangan limbah perkotaan ataupun pertanian (seperti limbah cair urin masyarakat maupun pupuk pertanian).

Hasil analisis korelasi matriks memperlihatkan bahwa semua parameter sumber pencemar non logam $\left(\mathrm{BOD}_{5}, \mathrm{TAN}\right.$, nitrat, fosfat, surfaktan, total coliform) memiliki hubungan positif dengan semua karakteristik perairan (suhu, kekeruhan, pH, salinitas, DO) (Tabel 4). Selain itu, Tabel 4 juga memperlihatkan bahwa sumber pencemar non logam total amonia nitrogen dan fosfat memiliki hubungan yang signifikan terhadap kualtas air suhu. Artinya, hubungan antara dua parameter tersebut sangat kuat dan saling memberikan pengaruh. Hasil ini didukung oleh kajian Rintaka et al. (2014), dimana suhu perairan yang rendah akan diikuti oleh peningkatan konsentrasi nutrien permukaan, baik itu fosfat, amoniak maupun silikat. Selanjutnya, Tabel 4 juga memperlihatkan bahwa sumber pencemar non logam nitrat memiliki hubungan yang signifikan terhadap parameter $\mathrm{pH}$, kekeruhan dan salinitas, sedangkan untuk kualitas air oksigen terlarut (DO) tidak memiliki hubungan yang kuat terhadap tinggi rendahnya sumber pencemar non logam di perairan waduk asin Pusong Kota Lhokseumawe, baik itu terhadap $\mathrm{BOD}_{5}$, total amonia nitrogen, nitrat, fosfat, surfaktan maupun total coliform.

Kompleksitas wilayah studi antar stasiun pengamatan, analisis CA memperlihatkan bahwa terjadinya pembentukan dua kelompok yang saling berbeda terhadap sumber pencemar non logam di perairan waduk asin Pusong Kota Lhokseumawe. Kelompok pertama terdiri dari Stasiun 2, 4 dan 5 dengan konsentrasi nitrat, $\mathrm{BOD}_{5}$ serta total coliform yang tinggi, sedangkan kelompok kedua terdiri dari Stasiun 1 dan 3 dengan konsentrasi total amonia nitrogen, fosfat dan surfaktan yang tinggi (Gambar 2). Pengelompokkan tersebut memperlihatkan adanya pengaruh dari berbagai aktivitas manusia yang ada di darat maupun di badan perairan, dimana pada kelompok

Tabel 3. Penjelasan total varians dan matriks komponen terhadap sumber pencemar non logam di perairan waduk asin Pusong Kota Lhokseumawe

\begin{tabular}{|c|c|c|c|c|c|c|c|c|c|}
\hline \multirow{2}{*}{$\begin{array}{c}\text { Co } \\
\text { m } \\
\text { pon } \\
\text { ent }\end{array}$} & \multicolumn{3}{|c|}{$\begin{array}{c}\text { Initial } \\
\text { Eigenvalues } \\
\end{array}$} & \multicolumn{3}{|c|}{$\begin{array}{c}\text { Extraction Sums of Squared } \\
\text { Loadings }\end{array}$} & \multicolumn{3}{|c|}{$\begin{array}{c}\text { Rotation Sums of Squared } \\
\text { Loadings }\end{array}$} \\
\hline & Total & $\begin{array}{c}\% \text { of } \\
\text { Variance }\end{array}$ & $\begin{array}{l}\text { Cumu } \\
\text { lative } \\
\text { (\%) }\end{array}$ & Total & $\begin{array}{c}\% \text { of } \\
\text { Variance }\end{array}$ & $\begin{array}{l}\text { Cumu } \\
\text { lative } \\
\text { (\%) }\end{array}$ & Total & $\begin{array}{c}\text { \% of } \\
\text { Variance }\end{array}$ & $\begin{array}{c}\text { Cumu } \\
\text { lative } \\
(\%)\end{array}$ \\
\hline \multicolumn{10}{|c|}{ Total variance explained } \\
\hline 1 & 3.050 & 50.84 & 50.84 & 3.050 & 50.84 & 50.84 & 2.766 & 46.11 & 41.45 \\
\hline 2 & 1.929 & 32.15 & 82.99 & 1.929 & 32.15 & 82.99 & 2.213 & 36.88 & 74.86 \\
\hline 3 & 0.900 & 15.01 & 97.99 & & & & & & \\
\hline 4 & 0.120 & 2.01 & 100.00 & & & & & & \\
\hline \multirow{2}{*}{\multicolumn{3}{|c|}{ Parameter }} & \multicolumn{3}{|c|}{ Component Matrix } & & \multicolumn{3}{|c|}{ Rotated Component Matrix } \\
\hline & & & PC 1 & & & & PC 1 & \multirow{2}{*}{\multicolumn{2}{|c|}{$\begin{array}{ll}\text { PC } 2 \\
0674\end{array}$}} \\
\hline \multicolumn{3}{|c|}{ Nitrat } & -0.946 & \multicolumn{2}{|c|}{0.230} & & -0.702 & & \\
\hline \multicolumn{3}{|c|}{ Total amonia nitrogen } & 0.841 & \multicolumn{2}{|c|}{0.488} & & 0.973 & & 0.002 \\
\hline \multicolumn{3}{|c|}{ Fosfat } & 0.822 & \multicolumn{2}{|c|}{0.545} & & \multicolumn{2}{|l|}{0.985} & 0.057 \\
\hline \multicolumn{3}{|c|}{ Surfaktan } & 0.760 & \multicolumn{2}{|c|}{-0.334} & & \multirow{2}{*}{0.489} & & -0.671 \\
\hline \multicolumn{3}{|c|}{$\mathrm{BOD}_{5}$} & -0.417 & \multicolumn{2}{|c|}{0.616} & & & -0.051 & 0.742 \\
\hline
\end{tabular}


Total coliform

$-0.142$

0.922

0.342

0.868

Tabel 4. Kondisi karakteristik perairan di perairan waduk asin Pusong Kota Lhokseumawe

\begin{tabular}{|c|c|c|c|c|c|}
\hline & Suhu & Kekeruhan & $\mathrm{pH}$ & Salinitas & DO \\
\hline $\mathrm{BOD}_{5}$ & $0.668 \mathrm{a}, \mathrm{ns}$ & $0.391 \mathrm{a}, \mathrm{ns}$ & $0.493 a, n s$ & $0.493^{a, n s}$ & $0.188^{a, n s}$ \\
\hline Total amonia nitrogen & $0.0144^{* * *}$ & $0.104^{a, n s}$ & $0.054 a, n s$ & $0.054 a, n s$ & $0.285^{a, n s}$ \\
\hline Nitrat & $0.111 \mathrm{a}, \mathrm{ns}$ & $0.000 a^{*}$ & $0.005^{a, *}$ & $0.005^{a, *}$ & $0.285^{a, n s}$ \\
\hline Fosfat & $0.0144^{* * *}$ & $0.104^{a, n s}$ & $0.054 a, n s$ & $0.054 a, n s$ & $0.285^{a, n s}$ \\
\hline Surfaktan & $0.734^{a, n s}$ & $0.188 a, n s$ & $0.322^{a, n s}$ & $0.269 a, n s$ & $0.873 a, n s$ \\
\hline Total coliform & $0.800^{a, n s}$ & $0.624 a, n s$ & $0.870 \mathrm{a}, \mathrm{ns}$ & $0.741^{a, n s}$ & $0.873^{a, n s}$ \\
\hline
\end{tabular}

ns $=$ Not Significant; ${ }^{*} P<0.01 ;{ }^{* *}=P<0.05$; aKoefisien Spearman

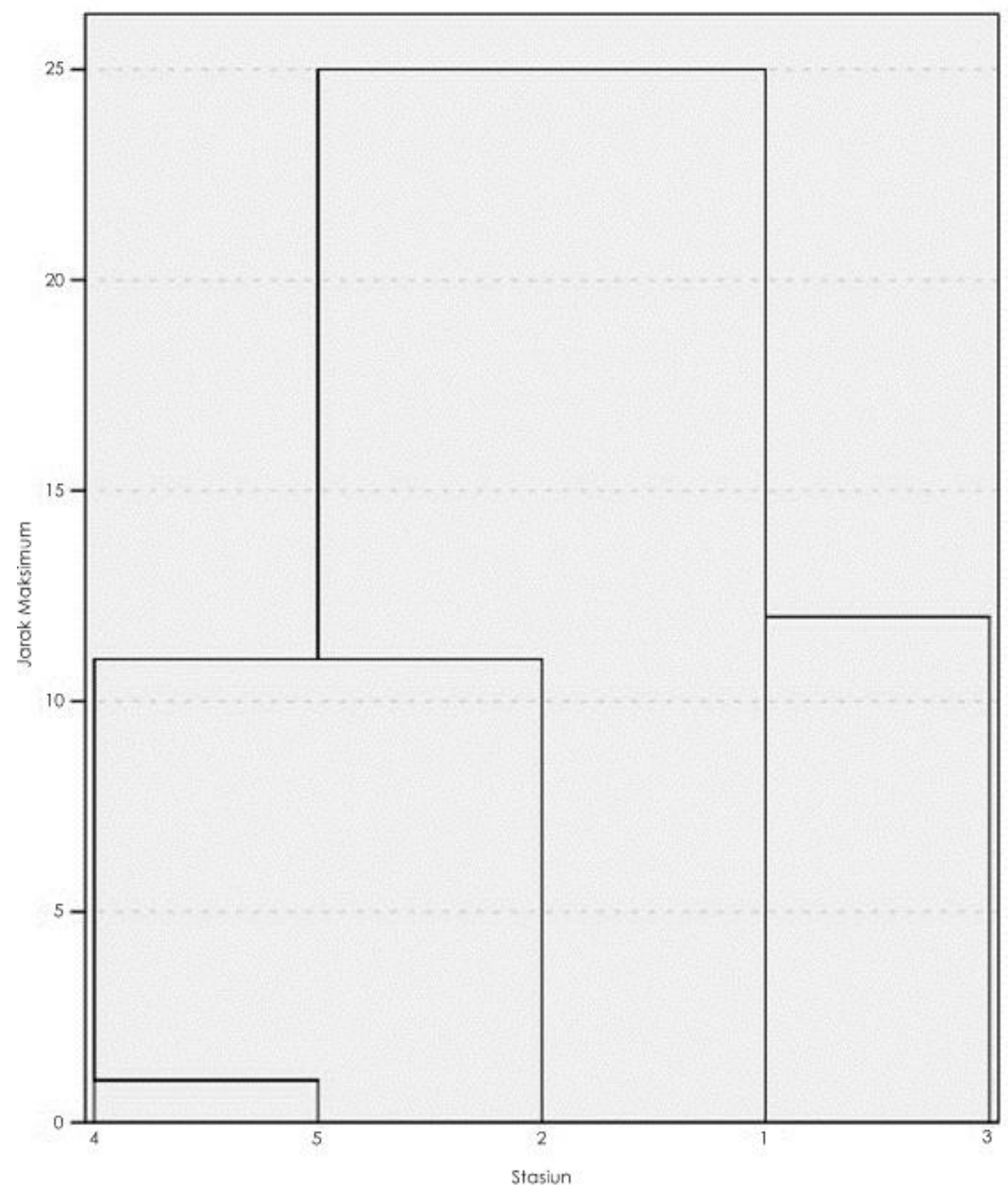


Gambar 2. Dendrogam sumber pencemar non logam di perairan waduk asin Pusong Kota Lhokseumawe

pertama (Stasiun 2, 4 dan 5) sangat berkaitan erat dengan area rekreasi, pasar tradisional dan budidaya keramba jaring tancap, sedangkan untuk kelompok kedua (Stasiun 1 dan 3) mengindikasikan adanya masukan limbah domestik dari daratan sekitar dan budidaya keramba jaring tancap di badan perairannya.

\section{KESIMPULAN}

Konsentrasi sumber pencemar non logam total amonia nitrogen, nitrat maupun fosfat di perairan waduk asin Pusong Kota Lhokseumawe sudah melebihi baku mutu yang telah ditetapkan, dimana nitrat dan total amonia nitrogen adalah parameter yang paling berpotensi sebagai sumber pencemar non logam di perairan tersebut dengan aktivitas antropogenik penyumbangnya adalah kegiatan budidaya keramba jaring tancap serta masukan limbah perkotaan yang berada di sekitarnya. Selain itu, sumber pencemar non logam nitrat memiliki hubungan yang signifikan terhadap kualitas air $\mathrm{pH}$, kekeruhan dan salinitas, sedangkan sumber pencemar non logam total amonia nitrogen memiliki hubungan yang signifikan terhadap kualitas air suhu, dimana untuk kompleksitas wilayah studi antar stasiun pengamatannya terjadi dua pengelompokkan yaitu kelompok pertama terdiri dari Stasiun 2 , 4 dan 5 dengan sumber pencemar non logamnya adalah nitrat, $\mathrm{BOD}_{5}$ serta total coliform, sedangkan kelompok kedua terdiri dari Stasiun 1 dan 3 dengan sumber pencemar non logamnya adalah total amonia nitrogen, fosfat dan surfaktan.

\section{UCAPAN TERIMA KASIH}

Ucapan terima kasih disampaikan kepada Lembaga Penelitian dan Pengabdian Kepada Masyarakat (LPPM) Universitas Malikussaleh yang telah memfasilitasi penulis dalam melakukan penelitian ini melalui dana Pendapatan Negara Bukan Pajak (PNBP) dalam Daftar
Isian Pelaksanaan Anggaran (DIPA) Universtas Malikussaleh tahun anggaran 2020.

\section{DAFTAR PUSTAKA}

Ak'habuhaya, J., \& Lodenius, M. 1998. Metal pollution of River Msimbazi, Tanzania, Environment International, 14(6):511-514. doi: 10.1016/0160-4120(88)90412-6.

Araujo, A.O., Mendonca, L.A.R., de Sousa Lima, M.G., Feitosa, J.V., da Silva, F.J.A., Ness, R.L.L., Frischkorn, H., Simplicio, A.A.F. \& Kerntopf, M.R. 2013. Changes in soil properties of a forest management area on the Araripe Plateau, Revista Brasileira de Ciencia do Solo, 37(3):754-762. doi: 10.1590/S0100-06832013000300022.

Bierman, P., Lewis, M., Ostendorf, B., \& Tanner, J. 2011. A review of methods for analysing spatial and temporal patterns in coastal water quality, Ecological Indicators, 11(1):103-114. doi: 10.1016/j. ecolind.2009. 11.001.

Dsikowitzky, L., Nordhaus, I., Jennerjahn, T.C., Khrycheva, P., Sivatharshan, Y., Yuwono, E. \& Schwarzbaver, J. 2011 . Anthropogenic organic contaminants in water, sediments and benthic organisms of the mangrove-fringed Segara Anakan Lagoon, Java, Indonesia, Marine Pollution Bulletin, 62(4):851-862. doi: 10.1016/j.marpolbul. 2011.02 .023$.

Effendi, H. 2016. River water quality preliminary rapid assessment using pollution index, Procedia Environmental Sciences, 33:562-567. doi: 10.1016/j.pro env.2016.03.108.

Einax, J.W., \& Soldt, U. 1999. Geostatistical and multivariate statistical methods for the assessment of polluted soils - merits and limitations. Chemometrics and Intelligent Laboratory Systems, 46(1):7991. doi: 10.1016/S0169-7439(98)00152-X.

Ejiadi, Badrun, Y., \& Gesriantuti, N. 2017. Serangga air sebagai bioindikator di Sungai Siak Kota Pekanbaru, Dalam: Prosiding Seminar Nasional $2^{\text {nd }}$ Celscitech 2017, 20 September 2017, Pekanbaru, Indonesia, $\mathrm{SCl} 1-9$.

Environment Canada. 2003. Canadian Water Quality Guidelines for the Protection of 
Aquatic Life: Nitrate Ions, Ecosystem Health: Science-based Solutions Report No. 1-6, National Guidelines And Standards Office, Water Policy Coordination Directorate, Environment Canada, 115 pp.

Facchinelli, A., Sacchi, E., \& Mallen, L. 2001. Multivariate statistical and GIS-based approach to identify heavy metal sources in soils, Environmental Pollution, 114(3): 313-324. doi: 10.1016/S0269$7491(00) 0024$ 3-8.

Garcia, R., Maiz, I., \& Millan, E. 1996. Heavy metal contamination analysis of roadsoils and grasses from Gipuzkoa (Spain), Environmental Technology, 17(7):763-770. doi: 10.1080/09593331708616443.

Hammer, O., Harper, D.A. \& Ryan, P.D. 2001. PAST: Paleontological statistics software: Package for education and data analysis, Palaeontologia Electronica, 4(1):1-9. doi: 10.1.1.459.1289.

Hamzah, F. \& Setiawan, A. 2010. Akumulasi logam berat $\mathrm{Pb}, \mathrm{Cu}$, dan $\mathrm{Zn}$ di hutan mangrove Muara Angke, Jakarta Utara, IImu dan Teknologi Kelautan Tropis, 2(2):41-52.

Handoko, T., Syofian, \& Tinov, M.Y.T. 2018. Collaborative governance dalam pengendalian pencemaran lingkungan oleh aktivitas industri pada Daerah Aliran Sungai (DAS) Siak di Kota Pekanbaru, Administrative Reform, 6(3):102-109.

Ismi, H., Amalia, A.R., Sari, N., Gesriantuti, N., \& Badrun, Y. 2019. Dampak mikroplastik terhadap makrozoobentos; suatu ancaman bagi biota di Sungai Siak, Pekanbaru, Dalam: Prosiding SainsTeKes Seminar Nasional MIPAKES 2019, 22 Agustus 2019, Pekanbaru, Indonesia, Bio pp. 92 - 104.

Johar, O.A. 2019. Pencemaran Sungai Siak di Kota Pekanbaru dan penegakan hukum pidana lingkungan, IImu Sosial dan Politik, 9(2):489-501.

Khatab, \& Indrawan. 2013. Evaluasi Waduk Pusong sebagai upaya pengendalian banjir di Kota Lhokseumawe Kabupaten Aceh Utara, Teknik Sipil USU, 2(3):1-10.

Khwedim, K., Meza-Figueroa, D., Hussien, L.A., \& Rio-Salas, R.D. 2015. Trace metals in topsoils near the Babylon Cement Factory (Euphrates River) and human health risk assessment, Environmental
Earth Sciences, 74:665-673. doi: 10.1007/ s12665-015-4071-x.

Kumar, V., Sharma, A., Kumar, R., Bhardwaj, R., Thukral, A.K., \& Rodrigo-Comino, J. 2018. Assessment of heavy-metal pollution in three different Indian water bodies by combination of multivariate analysis and water pollution indices, Human and Ecological Risk Assessment: An International Journal, 26(1):1-16. doi: 10.1080/10807039.2018.1497946.

Lins, R.C., Martinez, J., da Motta Marques, D., Cirilo, J.A., Medeiros, P.R.P., \& Junior, C.R.F. 2018. A multivariate analysis framework to detect key environmental factors affecting spatiotemporal variability of chlorophyll-a in a tropical productive estuarine-lagoon system, Remote Sensing, 10(853):p853. doi: 10.33 90/rs10060853.

Lucho-Constantino, C.A., Alvarez-Suarez, M., Beltran-Hernandez, R.I., Prieto-Garcıa, F., \& Poggi-Varaldo, H.M. 2005. A multivariate analysis of the accumulation and fractionation of major and trace elements in agricultural soils in Hidalgo State, Mexico irrigated with raw wastewater, Environment International, 31 (3):313-323. doi: 10.1016/j.envint.2004. 08.002.

Machiwa, J.F. 1992. Heavy metal content in coastal sediments off Dar Es Salaam, Tanzania, Environment International, 18(4):409-415. doi: 10.1016/0160-4120(92) 90073-D.

Mico, C., Recatala, L., Peris, M., \& Sanchez, J. 2006. Assessing heavy metal sources in agricultural soils of an European Mediterranean area by multivariate analysis, Chemosphere, 65(5):863-872. doi: 10.1016/j.chemosphere.2006.03.016.

[MNLH] Menteri Negara Lingkungan Hidup Republik Indonesia, 2004, Baku Mutu Air Laut untuk Biota Laut. Dalam: Keputusan Menteri Negara Lingkungan Hidup No. 51 Tahun 2004 Tentang Baku Mutu Air Laut, Jakarta - Indonesia.

Paul, D. 2017. Research on heavy metal pollution of River Ganga: A review, Annals of Agrarian Science, 15(2):278286. doi: 10.1016/j.aasci.2017.04.001.

Prasad, B., \& Sangita, K. 2008. Heavy metal pollution index of ground water of an abandoned open cast mine filled with fly 
ash: A case study. Mine Water and the Environment, 27(4):265-267. doi: 10.1007/ s10230-008-0050-8.

Radiarta, I.N., Ardi, I., \& Kristanto, A.H. 2013. Aplikasi analisis spasial dan statistik multivariat terhadap kondisi kualitas perairan di Selat Alas, Kabupaten Sumbawa, Nusa Tenggara Timur: Aspek penting untuk pengembangan budidaya rumput laut, Riset Akuakultur, 8(1):159171. doi : 10.15578/jra.8.1.2013. 159-171.

Ramseyer, L.J., \& Garling, D.L. 1997. Fish Nutrition and Aquaculture Waste Management, Department of Fisheries and Wildlife Michigan State University East Lansing, 48824

Reza, R., \& Singh, G. 2010. Heavy metal contamination and its indexing approach for river water, International Journal of Environmental Science \& Technology, 7(4):785-792. doi: 10.1007/ BF03326187.

Rintaka, W.E., Pancawati, Y., \& Tiadi, T.A. 2014. Pengaruh suhu terhadap distribusi klorofila dan nutrien (fosfat, amoniak, silikat) di perairan Selat Bali periode pengukuran April, Juni, Agustus 2013, Dalam: Prosiding Seminar Nasional Tahunan XI Hasil Penelitian Perikanan dan Kelautan, 30 Agustus 2014, Yogyakarta-Indonesia, KL05:327-336.

Sandra, R.Y., Siswani, R., Rahma, N., \& Sepryani, H. 2016. Analisis kandungan besi pada air Sungai Siak di Pekanbaru, Sains dan Teknologi Laboratorium Medik, $1(2): 2-5$.

Satheeshkumar, P., \& Khan, A.B. 2012. Identification of mangrove water quality by multivariate statistical analysis methods in Pondicherry coast, India, Environmental Monitoring and Assessment, 184(6):3761-3774. doi: 10.100 7/s10661-011-2222-4.

Singh, V.B., \& Ramanathan, A.L. 2015. Assessment of solute and suspended sediments acquisition processes in the Bara Shigri glacier meltwater (Western Himalaya, India). Environmental Earth Sciences, 74:2009-2018, doi: 10.1007/s12 665-015-4584-3.

Sudaryanto, \& Suherman, D. 2008. Degradasi kualitas airtanah berdasarkan kandungan nitrat di cekungan Jakarta, Riset Geologi dan Pertambangan, 18(2):61-68.
Sukadi, M.F. 2010. Ketahanan dalam air dan pelepasan nitrogen dan fosfor ke air media dari berbagai pakan ikan air tawar, Riset Akuakultur, 5(1):1-12.

Sumiarsih, E., Fajri, N.E., Adriman, Sanodri, T., \& Ritonga, R.M. 2018. Komunitas makrozoobenthos sebagai bioindikator pencemaran di perairan Sungai Siak, Pekanbaru. Asian Journal of Environment, History and Heritage. 2(1):19-28.

Supriyantini, E., Nuraini, R.A.T., \& Fadmawati, A.P. 2017. Studi kandungan bahan organik pada beberapa muara sungai di kawasan ekosistem mangrove, di wilayah pesisir pantai Utara Kota Semarang, Jawa Tengah, Buletin Oseanografi Marina, 6(1):29-38.

Syahrial. 2019. Studi komparatif morfologi mangrove Rhizophora apiculata pada kawasan industri perminyakan dan kawasan non industri Provinsi Riau, Maspari, $11(1): 31-40$.

Syahrial, Sustriani, Y., Susammesin, V.A., Taher, D.P., Atikah, N., Lubis, K.M., llahi, I., Mulyadi, A., Amin, B., \& Siregar, S.H. 2017, Regenerasi alami semai Rhizophora apiculata di kawasan industri perminyakan dan kawasan non industri Provinsi Riau, Enggano, 2(2):208-217.

Syahrial, Bengen, D.G., Prartono, T., \& Amin, B. 2018a. Faktor yang mempengaruhi kesehatan populasi Rhizophora apiculata berdasarkan karakteristik lingkungan pada kawasan industri perminyakan dan non kawasan industri di Provinsi Riau menggunakan analisis komponen utama (PCA), Enggano, 3(2):228-240.

Syahrial, Bengen, D.G., Prartono, T., \& Amin, B. 2018b. kondisi kesehatan dan variasi spasial karakteristik populasi Rhizophora apiculata pada kawasan industri perminyakan dan non industri di Provinsi Riau, Perikanan dan Kelautan, 8(2):126-143.

Syahrial \& Novita. 2018. Inventarisasi mangrove dan gastropoda di Pulau Tunda Serang Banten, Indonesia serta distribusi spasial dan konektivitasnya, Saintek Perikanan, 13(2):94-99.

Syahrial, Purwanti, N., Sagala, H.A.M.U., Atikah, N., Sari, Y., Oktavian, B., \& Simbolon, N. 2019a. Karakteristik lingkungan dan kondisi fauna makrobentik di kawasan reboisasi 
mangrove Pulau Pramuka, Panggang, dan Karya, Kepulauan Seribu, Indonesia, IImiah Perikanan dan Kelautan, 11(1):920.

Syahrial, Fahriansyah, Lilian, A., Arbaeyah, Tanjung, C.F., \& Lubis, N.S. 2019b. Karakteristik lingkungan penentu distribusi dan kepadatan fauna makro bentik serta hubungannya: Studi kasus gastropoda dan kepiting brachyura di kawasan reboisasi mangrove Kepulauan Seribu, Saintek Perikanan, 15(1):1-10.

Syahrial, Pranata, E., \& Susilo, H. 2019c. Korelasi faktor lingkungan dan distribusi spasial komunitas moluska di kawasan reboisasi mangrove Kepulauan Seribu, Indonesia, Torani, 2(2):44-57.
Tyagi, S., Sharma, B., Singh, P., \& Dobhal, R. 2013. Water quality assessment in terms of water quality index, American Journal of Water Resources, 1(3):34-38. doi: 10.12691/AJWR-1-3-3.

Wolf, H.D., \& Rashid, R. 2008. Littoraria scabra along polluted and pristine mangrove areas of Tanzania, Environmental Pollution, 152(3):636-643. doi: 10.1016/j. envpol.2007.06.064.

Yan, F., Yuhong, W., Yihao, L., Hua, X, \& Zhenbo, L. 2012. Feature of phytoplankton community and canonical correlation analysis with environmental factors in Xiaoqing River estuary in autumn, Procedia Engineering, 37:19-24. doi: 10.1016/j.proeng.2012.04. 195. 